Analysis of Hexanitrostilbene (HNS) and Dipicryethane (DPE) for Mutagenicity by the Ames/Salmonella Assay

R. Wu, J. Felton

October 18, 2007 
This document was prepared as an account of work sponsored by an agency of the United States government. Neither the United States government nor Lawrence Livermore National Security, LLC, nor any of their employees makes any warranty, expressed or implied, or assumes any legal liability or responsibility for the accuracy, completeness, or usefulness of any information, apparatus, product, or process disclosed, or represents that its use would not infringe privately owned rights. Reference herein to any specific commercial product, process, or service by trade name, trademark, manufacturer, or otherwise does not necessarily constitute or imply its endorsement, recommendation, or favoring by the United States government or Lawrence Livermore National Security, LLC. The views and opinions of authors expressed herein do not necessarily state or reflect those of the United States government or Lawrence Livermore National Security, LLC, and shall not be used for advertising or product endorsement purposes.

This work performed under the auspices of the U.S. Department of Energy by Lawrence Livermore National Laboratory under Contract DE-AC52-07NA27344. 


\title{
Analysis of Hexanitrostilbene (HNS) and Dipicryethane (DPE) for Mutagenicity by the Ames/Salmonella Assay
}

\author{
Rebekah W.Wu, James S. Felton \\ CMELS, Lawrence Livermore National Laboratory \\ (Contracted through the Atomic Weapons Establishment, UK)
}

\section{INTRODUCTION}

The Ames/Salmonella assay, developed by Professor Bruce Ames at the University of California, Berkeley, is a rapid and sensitive assay for detecting mutagenicity of various chemical compounds (Maron and Ames, 1983). It is a widely accepted short-term assay for detecting chemicals that induce mutations in the histidine (his) gene of Salmonella typhimurium. This is a reverse mutation assay that detects the mutational reversion of his-dependent Salmonella to the his-independent counterpart. Thereby, mutagenic compounds will increase the frequency of occurrence of his-independent bacterial colonies. The assay utilizes the specific genetically constructed strains of bacteria either with or without mammalian metabolic activation enzymes (S9), Aroclor induced rat liver homogenate) to assess the mutagenicity of different compounds. In this study, we will use the Ames/Salmonella assay to investigate the mutagenicity of Hexanitrostilbene (HNS) from both Bofors and Pantex, and Dipicryethane (DPE).

\section{MATERIALS AND METHODS}

\section{Chemicals}

The Atomic Weapons establishment in the UK provided us with HNS from Bofors and Pantex, and DPE was obtained from BWXT Pantex, LLC. Dimethylformamide (DMF), the solvent used to dissolve the compounds, was obtained from J.T. Baker Chemical Co.. All other chemicals and bacteriological media were of best quality from standard sources. 


\section{Bacterial strains}

Salmonella typhimurium strains TA98 and TA100 were kindly provided by Dr. Bruce Ames (University of California, Berkeley, CA). TA98 is sensitive to frameshift inducing mutagens, whereas TA100 to base substitution inducing mutagens.

Salmonella typhimurium strain YG1024 was a generous gift of Dr. T. Nohme (National Institute of Heath Sciences, Tokyo). YG1024 is a derivative of S. typhimurium TA98 with a high expression level of O-acetyltransferase activity (Watanabe et al. 1990) in addition to its sensitivity to the frame-shift inducing mutagens.

\section{Mutation assay}

The Microsuspension plating method (Kado et al., 1983) was used to evaluate the mutagenicity of HNS and DPE. It is a highly sensitive plating method for testing the mutagenicity of pure chemicals available only in small amounts. The mutation assay is briefly described. Bacteria were grown overnight in Oxoid Nutrient Broth No.2 to approximately $10^{9}$ bacteria/ml and harvested by centrifugation $\left(5000 \mathrm{x} \mathrm{g}, 4^{\circ} \mathrm{C}, 10 \mathrm{~min}\right)$. The pellet was washed once in cold phosphate -buffered saline (PBS, 0.15M, pH7.4) and resuspended in ice-cold PBS at a final concentration of $1 \times 10^{10}$ bacteria/ml (10-fold concentration). The assay tube consisted of $0.1 \mathrm{ml}$ of the concentrated bacteria, $0.1 \mathrm{ml}$ of PBS and different concentrations of the tested compound. The volume of the tested compound added should not exceed $20 \mu 1$. From our study, we found that these compounds did not require metabolic activation. Therefore, S9 was not added. The mixture was then incubated for 90 min at $37^{\circ} \mathrm{C}$ with constant mixing at $120 \mathrm{rpm}$. Next, 2 $\mathrm{ml}$ of molten top agar was added immediately to the incubated mixture and poured onto the minimal glucose agar plates. The plates were incubated for $48 \mathrm{hr}$ at $37^{\circ} \mathrm{C}$. Bacterial colonies were scored using the Artek Counter, model 888 (Imaging Products International, Chantilly, Virginia).

\section{RESULTS, DISCUSSION}


Preliminary requirements were investigated before the study. The mutagenicity of DMF, used for dissolving HNS and DPE, was evaluated in the Ames Assay. A different amount of DMF was tested using bacteria TA98 with and without metabolic activation (S9) shown in Fig.1. The numbers of revertants per plate from both conditions were similar to that of DMSO, which was used as background controls in our laboratory. Therefore, DMF was not mutagenic in the Ames assay. HNS from Bofors and Pantex were dissolved

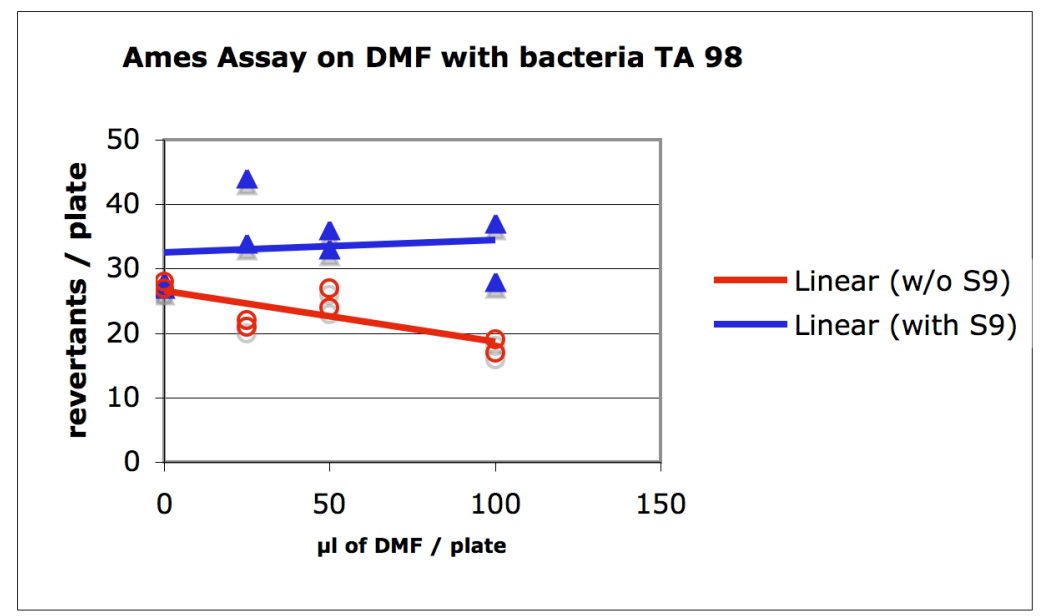

in DMF at $10 \mathrm{mg} / 600 \mu \mathrm{l}$ and $10 \mathrm{mg} / 800 \mu 1$, respectively. DPE was dissolved in $10 \mathrm{mg} / 200 \mu 1$ of DMF

Fig.1

To establish the best plating method, we compared the Microsuspension and Preincubation plating methods (Zeiger and Mortelmans, 1999). The mutation potency of HNS (Pantex) in TA98 with Microsuspension and Preincubation plating method was 5467 revertants/mg, 1130 revertants, respectively. The mutation potency of HNS in Microsuspension plating method was four-fold more potent than that of the Preincubation method. Therefore, the Microsuspension plating method was used for all subsequent mutation studies of the three compounds.

The requirement of metabolic activation (S9) was studied in HNS from both Bofors and Pantex shown in Fig. 2A and 2B below. Since bacteria lack most of the mammalian enzymes necessary for metabolic activation, an external supply of these enzymes (S9) was added. Our study showed both compounds were mutagenic with dose response sensitivity. However, the metabolic activation did not play a significant role in the 
mutagenic response indicating these compounds were direct mutagens. Therefore, S9 was not required for the study of these compounds

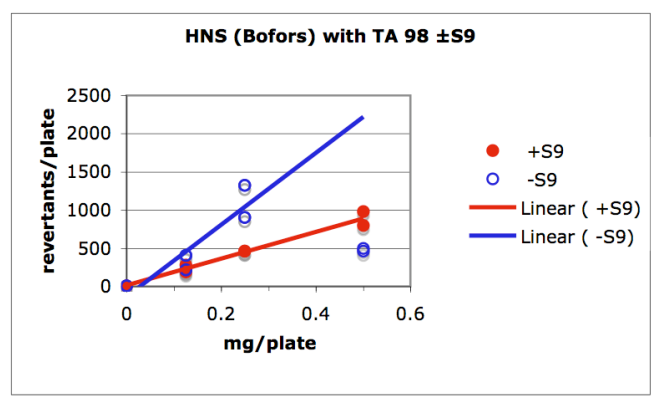

Fig. 2A

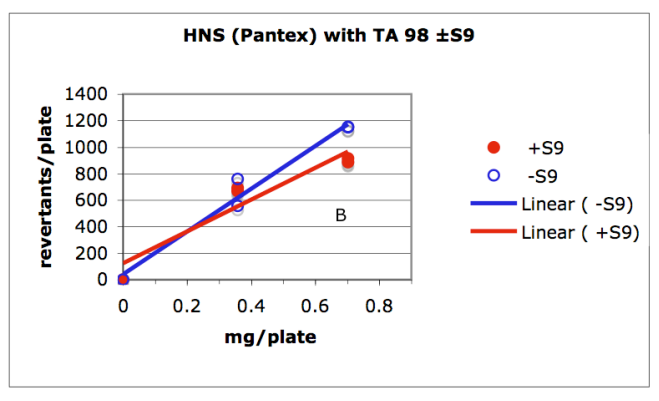

Fig. 2B

In the Ames assay, each chemical was subjected to three strains of bacteria, TA98, TA100 and YG1024 without metabolic activation. For each experiment, a positive control containing standard diagnostic mutagens specific for each bacteria strain, and also a solvent control showing revertants from background spontaneous mutagenesis were included.

For each chemical, the dose-response curve was generated from a minimum of four dose points in replicates of two. Each experiment was repeated two or three times. The final summary was the average of these experiments, and was presented graphically as dose-response curve. The mutagenic profile of each chemical was expressed as mutagenic potency. Mutagenic potency was expressed as the revertant colonies $/ \mathrm{mg}$ of the tested compound. It was calculated from the linear portion of the dose-response curve. Additionally, the arbitrary two-fold rule (Cariello and Piegosch, 1996; Glatt and Meinl, 2004) can also be used to seek out the mutagenicity of the compound. Using this rule, a positive response requires a dose-response that reaches at least 2 - fold over the background spontaneous revertants.

Fig. 3 illustrated the dose-response curve of HNS (Bofors), HNS (Pantex) and DPE with TA 98. They were all mutagenic with dose-response sensitivity with HNS (Pantex) being the most potent followed by HNS (Bofors) and DPE. The mutagenic profile can be 
concluded as HNS (Pantex) $>$ HNS (Bofors) $>$ DPE, and in accordance with the mutagenic potency calculation (Table 1) and the arbitrary two-fold rule.

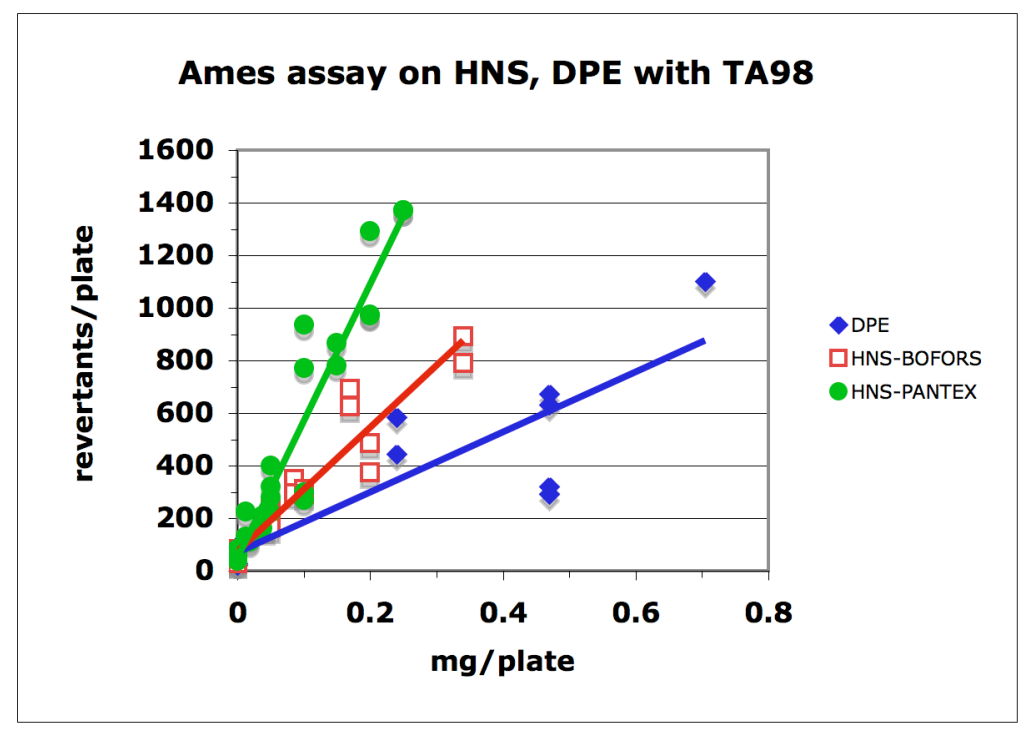

Fig.3

Fig. 4 illustrated that in bacteria YG1024, all compounds showed a clear dosedependent positive response, with HNS (Pantex) being the most mutagenic. The dose response curves of HNS (Bofors) and DPE were almost identical. The mutagenic potency of all three compounds was significantly higher than that shown by TA98. As previously mentioned, YG1024 was a derivative of TA98 and with a high expression level of $O$-acetyltransferase activity in addition to its sensitivity to the frame-shift inducing mutagens. Watanabe et al. (1993) demonstrated that YG1024 was highly sensitive to the mutagenic actions of $\mathrm{N}$-hydroxyarylamines derived from aromatic amines and nitroarenes. Since all these compounds belonged to the class of nitroarenes, their mutgenicity were further enhanced by the activation of O-acetyltransferase (Glatt and Meinl, 2004). As a result, their mutagenic potencies were also higher than that shown by TA98. 


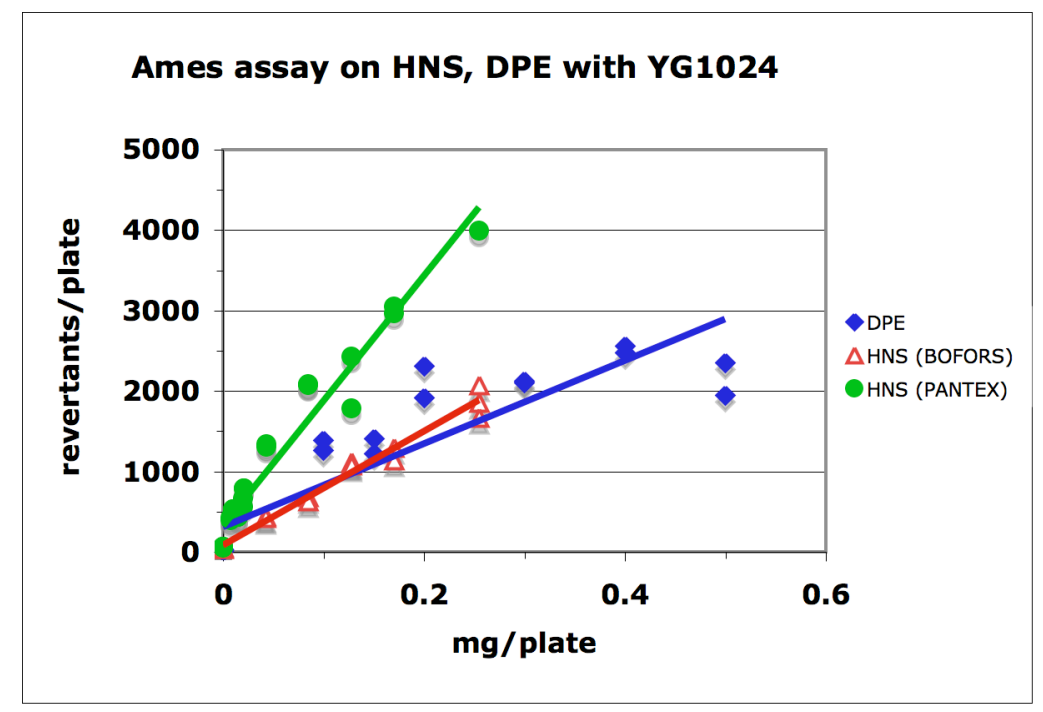

Fig. 4

In TA100 (Fig.5), the mutagenic responses of both HNS were very weak. The mutagenic potencies of HNS (Bofors) and HNS (Pantex) were 400 and 414, respectively (Table 1), and the fold increase over the spontaneous revertants was less than two-fold. Therefore, they were not base substituting inducing mutagens. DPE, with a mutagenic potency of 1316, and a 2.3 fold increase over the spontaneous revertants, was a weak base-substitution inducing mutagen. 


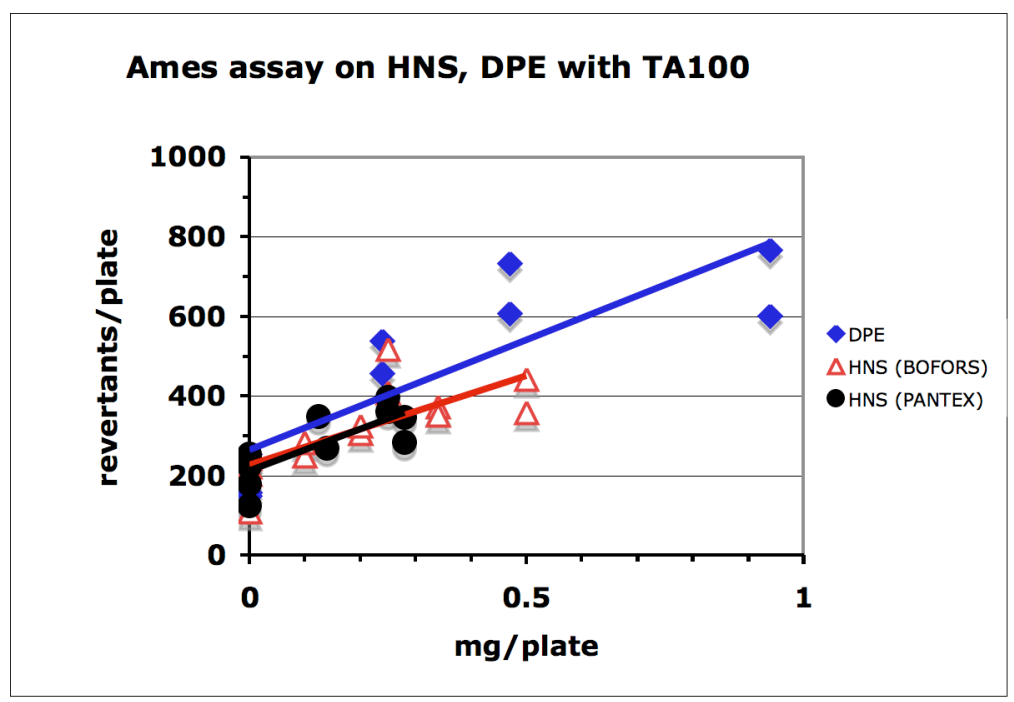

Fig. 5

In the Ames assay, all three compounds show good dose-response sensitivity in TA98, YG1024 and TA100. They are direct mutagens without the need of metabolic activation. Based upon the mutagenic potency (Table 1), we conclude that the mutagenic profile of these compounds are as follows; TA 98, HNS (Pantex) > HNS (Bofors) > DPE; YG1024, HNS (Pantex) $>$ HNS (Bofors) >DPE; TA100, DPE > HNS (Pantex) > HNS (Bofors). Among the three compounds, HNS (Pantex) is the most potent mutagen in both TA98 and YG1024. They are all frame-shift inducing mutagens due to their strong mutagenic response in TA98 and YG1024, and not base-substitution due to their negligible and weak response in TA100.

When the mutagenic potencies of these three compounds are compared to that of the food derived heterocyclic amine mutagens such as IQ and PhIP, they are not as potent. With TA98, the mutagenic potency is $194,000 / \mu \mathrm{g}$ for IQ, and 1700/ $\mu \mathrm{g}$ for PhIP. With the same strain, the mutagenic potencies for HNS (Bofors), HNS (Pantex) and DPE are 2456/mg, 5467/mg, 1192/mg, respectively. From our study, we can conclude that HNS from both Bofors and Pantex, and DPE belong to the class of frame-shift inducing mutagens. 
Table 1

\begin{tabular}{|l|l|l|}
\hline Bacteria & Compounds & $\begin{array}{l}\text { Mutagenic Potency } \\
\text { (revertants/mg. of } \\
\text { compound) }\end{array}$ \\
\hline TA98 & HNS (Bofors) & 2456 \\
\hline & HNS (Pantex) & 5467 \\
\hline & DPE & 1192 \\
\hline YG1024 & & \\
\hline & HNS (Bofors) & 6388 \\
\hline & HNS (Pantex) & 16453 \\
\hline & DPE & 6060 \\
\hline TA100 & & \\
\hline & HNS (Bofors) & 400 \\
\hline & HNS (Pantex) & 414 \\
\hline & DPE & 1316 \\
\hline
\end{tabular}

Mutation potency is calculated as revertans minus spontanoues revertants (obtained from the linear

regression dose curve) divided by the concentration of the compound.

\section{ACKNOWLEDGMENTS}

We thank Patricia Lewis for monitoring and weighing out the compounds.

This work is performed under the auspices of the U.S. Department of Energy by Lawrence Livermore National Laboratory under Contract DE-AC52-07NA27344 and supported by Atomic Weapons Establishment, UK.

This document was prepared as an account of work sponsored by an agency of the United States government. Neither the United States government nor Lawrence Livermore National Security, LLC, nor any of their employees makes any warranty, expressed or implied, or assumes any legal liability or responsibility for the accuracy, completeness, or usefulness of any information, apparatus, product, or process disclosed, or represents that its use would not infringe privately owned rights. Reference herein to any specific commercial product, process, or service by trade name, trademark, manufacturer, or otherwise does not necessarily constitute or imply its endorsement, recommendation, or favoring by the United States government or Lawrence Livermore National Security, LLC. The views and opinions of authors expressed herein do not necessarily state or reflect those of the United States government or Lawrence Livermore National Security, LLC, and shall not be used for advertising or product endorsement purposes. 


\section{REFERENCES}

Felton JS and Wu R (2003) Ames / Salmonella Assay: A Bacterial Test for Mutagens. Encyclopedia of Life Sciences. Nature Publishing Group.

Glatt H and Meinl W (2004) Use of genetically manipulated Salmonella typhimurium strains to evaluate the role of sulfotransferases and acetyltransferases in nitrofen metagenicity. Carcinogenisis Vol. 25, No. 5, 779-786.

Kado NY, Langley D and Eisenstadt E (1983) A simple modification of the Salmonella liquid incubation assay: Increase sensitivity for detecting mutagens in human urine.

Mutat. Res. 112: 25-32.

Maron EC and Ames BN (1983) Revised methods for the Salmonella mutagenicity test. Mutat. Res. 113:173-215.

Watanabe M, Ishidate M and Nohmi T. (1990) Sensitive method for the detection of mutagenic nitroarenes and aromatic amines: new derivatives of Salmonella typhimurium tester strains possessing elevated $O$-acetyltransferase levels. Mutat. Res. 234: 337-348.

Watanabe M, Sofuni T and Nohmi T (1993) Comparison of the sensitivity of Salmonella typhimurium strains YG1024 and YG1012 for detecting the mutagenicity of aromatic amines and nitroarenes. Mutat. Res. 301 (1): 7-12.

Zeiger E and Mortelmans K. (1999) Current protocols in Toxicology 3.1.1-3.1.29. Copyright by John Wiley \& Sons, Inc. 